\title{
Pengaruh Rasio Keuangan Terhadap Pertumbuhan Laba Perusahaan Perbankan
}

\author{
Febrianty $^{1 *}$, Divianto ${ }^{2}$ \\ Politeknik PalComTech ${ }^{1}$, Politeknik Negeri Sriwijaya ${ }^{2}$ \\ *Korespondensi: tebrianty@palcomtech.ac.id
}

Diserahkan: 22 Juli 2017, Direvisis: 28 Agustus 2017 Diterima: 9 September 2017

\begin{abstract}
The purpose of this study is to analyze the financial ratios to profit growth of banking companies in BEI. Researchers conduct research development by increasing the use of more financial ratios in viewing profit growth, namely: liquidity ratio, solvency ratio, profitability ratio, bank financial ratios, and market ratios. The type of data used in this study is secondary data in the form of annual reports of banking companies listed on the Stock Exchange in 2012-2016, the data used is cross section data. Sampling technique used is purposive sampling, so the samples obtained 14 banking companies. The analysis technique used is multiple regression. The results showed that only ROE variable that partially affect the profit growth in banking companies in the period 2012-2016. While BOPO, DAR, ROE, LAR, RR, NPL, CAR, DPR, CR, Cash Ratio, TIE, PER simultaneously have significant effect to profit growth in banking company in BEI period 2012-2016.

Keywords: Ratio, Finance, Growth, Profit, Banking.
\end{abstract}

\begin{abstract}
Abstrak
Tujuan penelitian ini adalah menganalisis rasio-rasio keuangan terhadap pertumbuhan laba perusahaan perbankan di BEI. Peneliti melakukan pengembangan penelitian dengan menambah penggunaan lebih banyak rasio keuangan dalam melihat pertumbuhan laba, yaitu: rasio likuiditas, rasio solvabilitas, rasio profitabilitas, rasio keuangan bank, dan rasio pasar. Jenis data yang digunakan dalam penelitian ini berupa data sekunder berupa laporan tahunan perusahaan perbankan yang terdaftar di BEI pada tahun 2012-2016 dalam, data yang digunakan adalah data cross section. Teknik sampling yang digunakan adalah purposive sampling, sehingga sampel yang didapatkan 14 perusahaan perbankan. Teknik analisis yang digunakan adalah regresi berganda. Hasil penelitian menunjukan bahwa hanya variabel ROE yang berpengaruh signifikan secara parsial terhadap pertumbuhan laba pada perusahaan perbankan di BEI periode 2012-2016. Sedangkan BOPO, DAR, ROE, LAR, RR, NPL, CAR, DPR, CR, Cash Ratio, TIE, PER secara simultan berpengaruh signifikan terhadap pertumbuhan laba pada perusahaan perbankan di BEI periode 2012-2016.
\end{abstract}

Kata Kunci: Rasio, Keuangan, Pertumbuhan, Laba, Perbankan

\section{A. PEndahuluan}

Stabilisasi perekonomian ditentukan oleh banyak faktor baik fundamental maupun teknis, salah satu penggerak perekonomian di Indonesia adalah sektor perbankan yang mempunyai tugas utama sebagai lembaga penghimpun dan penyalur dana masyarakat (UU No.10 tahun 1998 tentang Perbankan). Lembaga perbankan memiliki peran sebagai alternatif sumber modal untuk menggerakkan sektor rill, mendanai proyek negara, dan juga membiayai kebutuhan masyarakat umum. Sebagaimana perusahaan pada umumnya, bank juga berorientasi untuk mendapatakan laba yang maksimum serta menjaga kelangsungan usaha yang baik.

Laba bersih perbankan dominan diperoleh dari realisasi pendapatan bunga bersih. Laba yang terus mengalami peningkatan menunjukkan bahwa perusahaan perbankan mengalami 
laba bersih perbankan dominan diperoleh dari realisasi pendapatan bunga bersih. Laba yang terus mengalami peningkatan menunjukkan bahwa perusahaan perbankan mengalami peningkatan efisiensi dan efektivitas kegiatan operasionalnya secara periodik. Bagi para investoryang melihat pertumbuhan laba sebagai indikator kinerja perusahaan akan menggunakannya dalam pengambilan keputusan investasi, karena investor mengharapkan laba perusahaan pada periode berikutnya lebih baik dari periode sebelumnya. Oleh karena itu, jika laba perusahaan perbankan mengalami pertumbuhan positif, akan memancing para investor lain untuk berinvestasi di perusahaan (Purwanto, 2017). Salah satu yang termasuk dalam analisis laporan keuangan adalah rasio keuangan. Menurut Oktanto dan Muhammad Nuryanto (2014) menjelaskan bahwa rasio keuangan adalah penggabungan yang menunjukkan hubungan antara suatu unsur dengan unsur lainnya dalam laporan keuangan, hubungan antara unsur laporan tersebut dinyatakan dalam bentuk matematis yang sederhana. Oleh karena itu, rasio keuangan juga digunakan untuk memprediksi laba pada waktu mendatang.

Perolehan laba pada kelompok bank mengalami fluktuasi pada tiga tahun terakhir terhitung dari tahun 2013-2015. Tabel 1. menyajikan perkembangan laba pada perusahaan perbankan di Indonesia dari tahun 2013-2015 berdasarkan data Statistik Perbankan Indonesia, 2015:

Tabel 1: Perkembangan Laba Pada Perusahaan Perbankan di Indonesia Tahun 2013-2015 (dalam milliar rupiah)

\begin{tabular}{llll}
\hline \multirow{2}{*}{ Kelompok Bank } & \multicolumn{3}{c}{ Tahun } \\
\cline { 2 - 4 } & $\mathbf{2 0 1 3}$ & $\mathbf{2 0 1 4}$ & $\mathbf{2 0 1 5}$ \\
\hline Bank Umum & 106.707 & 112.160 & 104.628 \\
Bank Persero & 48.762 & 54.375 & 55.861 \\
Bank Umum Swasta Nasional Devisa & 33.469 & 32.860 & 29.129 \\
Bank Umum Swasta Nasional non Devisa & 3.084 & 2.316 & 2.084 \\
BPD & 10.733 & 9.667 & 10.595 \\
Bank Campuran & 4.538 & 4.219 & 1.793 \\
Bank Asing & 6.121 & 8.724 & 5.166 \\
\hline \multicolumn{1}{c}{ Sumber :Statistik Perbankan Indonesia } & $2015($ http $/ /$ www bi.go id)
\end{tabular}

Berdasarkan tabel di atas dapat diketahui bahwa laba disetiap tahun mengalami kenaikan dan penurunan. Perubahan kondisi tersebut, menuntut lembaga perbankan untuk memiliki kemampuan lebih baik dalam mengelola bisnisnya agar dapat bertahan. Laba menjadi faktor yang sangat penting terkait dengan kesinambungan dan stabilitas bisnis perbankan. Semakin tinggi laba yang dicapai maka dapat menjamin pendapatan untuk kreditor dan pemegang saham. Tingkat laba yang semakin besar akan menambah kepercayaan pihak investor atau deposan dalam menanamkan modalnya di perusahaan. Salah satu cara yang diyakini dapat memprediksi laba perusahaan adalah dengan mengunakan rasio keuangan. Menurut Mujati S. dan Dzulqodah (2016) menyatakan bahwa analisis internal perusahaan dapat diukur dari laporan keuangan setiap periode yang berasal dari neraca dan laporan laba rugi. Analisis laporan keuangan menyangkut rasio-rasio keuangan perusahaan yang dapat menggambarkan kinerja perusahaan. 
Guna mengetahui apakah perusahaan mendapatkan laba atau mengalami pertumbuhan laba maka dapat dilakukan dengan menghitung dan menginterprestasikan rasio-rasio keuangan perusahaan. Penelitian ini dilakukan juga untuk menguji kembali hubungan rasio-rasio keuangan dengan pertumbuhan laba. Secara teoritis, rasio keuangan dikatakan memiliki kemampuan jika dapat memprediksi fenomena ekonomi, salah satunya yakni perubahan laba dan harus mampu mengukur posisi keuangan perusahaan (Yasmin, 2017). Oleh karena itulah penelitian ini dilakukan untuk menguji secara empiris kekuatan prediksi rasio keuangan atas perubahan laba perusahaan. Seperti yang diketahui pertumbuhan laba dipengaruhi oleh perubahan komponen-komponen dalam laporan keuangan. Pertumbuhan laba yang disebabkan oleh perubahan komponen laporan keuangan misalnya perubahan penjualan, perubahan harga pokok penjualan, perubahan beban operasi, perubahan beban bunga, perubahan pajak penghasilan, adanya perubahan pada pos-pos luar biasa, dan lain-lain. Faktor-faktor luar seperti: kebebasan manajerial yang membuat flesibilitas manajer memilih metode akuntansi dan membuat estimasi yang dapat meningkatkan laba perusahaan, peningkatan harga akibat inflasi merupakan contoh hal yang menyebabkan perubahan laba.

Ketidakkonsistenan hasil dari penelitian-penelitian sebelumnya menyebabkan isu ini tetap menarik untuk diteliti kembali. Penelitian Safitri (2016) mengenai Pengaruh Rasio Keuangan terhadap Pertumbuhan Laba pada Perusahaan Manufaktur Sektor Industri Konsumsi yang Terdaftar di Bursa Efek Indonesia (Studi Kasus pada Perusahaan Kalbe Farma Tbk Periode 2007-2014). Hasil penelitian menunjukan Variabel Debt to Asset Ratio memiliki pengaruh signifikan terhadap pertumbuhan laba PT. Kalbe Farma tbk, Variabel Net profit margin dan Return on Equity secara parsial tidak berpengaruh signifikan terhadap pertumbuhan laba PT. Kalbe Farma tbk. Penelitian yang dilakukan oleh Gunawan dan Sri Fitri Wahyuni (2013) yang berjudul Pengaruh Rasio Keuangan terhadap Pertumbuhan Laba pada Perusahaan Perdagangan di Indonesia. Ada pengaruh yang signifikan Total Assets Turnover, Fixed Assets Turnover, Inventory Turnover terhadap pertumbuhan laba. Current Ratio, Debt To Assets Ratio, Debt To Equity Ratio tidak memiliki pengaruh yang signifikan terhadap pertumbuhan laba. Total Assets Turnover, Fixed Assets Turnover, Inventory Turnover, Current Ratio, Debt to Assets Ratio dan Debt to Equity Ratio secara bersama-sama berpengaruh signifikan terhadap Pertumbuhan Laba. Penelitian lainnya yang dilakukan oleh Mahaputra (2012) yang berjudul "Pengaruh RasioRasio Keuangan terhadap Pertumbuhan Laba pada Perusahaan Manufaktur yang Terdaftar di BEI". Penelitian menyatakan bahwa current ratio, debt to equity, total assets turnover, dan profit margin memiliki pengaruh signifikan terhadap pertumbuhan laba, yang mengindikasikan bahwa rasio-rasio tersebut mempengaruhi investor dalam mengambil keputusan investasi.

Tujuan penelitian ini adalah menganalisis pengaruh rasio-rasio keuangan terhadap pertumbuhan laba perusahaan perbankan di BEI. Peneliti melakukan pengembangan penelitian dengan menambah penggunaan lebih banyak rasio keuangan dalam melihat pertumbuhan laba, yaitu: rasio likuiditas, rasio solvabilitas, rasio profitabilitas, rasio keuangan bank, dan rasio pasar. 


\section{B. LANDASAN TEORI Teori Stakeholder}

Ghozali dan Chariri (2007) menyatakan bahwa Stakeholder Theory perusahaan bukanlah entitas yang beroperasi untuk kepentingannya sendiri namun harus memberikan manfaat bagi para stakeholder (pemegang saham, kreditor, konsumen, supplier, pemerintah, masyarakat, dan pihak lain). Salah satu kelompok yang menjadi bahan pertimbangan bagi manajemen perusahaan dalam mengungkapkan atau tidak suatu informasi di dalam laporan keuangan adalah kelompok Kelompok stakeholder. Tujuan utama dari teori stakeholder adalah untuk membantu manajemen perusahaan dalam meningkatkan penciptaan nilai sebagai dampak dari aktivitas yang dilakukan dan menimbulkan kerugian yang muncul bagi stakeholder. Dengan kata lain, dukungan yang diberikan oleh stakeholder kepada perusahaan sangat mempengaruhi keberadaan suatu perusahaan.

Teori Stakeholder mampu menjelaskan antara hubungan perusahaan dengan stakeholder-nya. Stakeholder pada dasarnya dapat mengendalikan atau memiliki kemampuan untuk mempengaruhi pemakaian sumber-sumber ekonomi yang digunakan perusahaan. Power stakeholder ditentukan oleh besar kecilnya kekuatan yang dimiliki oleh stakeholder atas sumber-sumber tersebut. Dengan kata lain, teori ini menyatakan bahwa kesuksesan dan hidup matinya suatu perusahaan sangat tergantung pada kemampuannya menyeimbangkan beragam kepentingan dari para stakeholder atau pemegang kepentingan. Jika mampu, maka perusahaan akan meraih dukungan yang berkelanjutan dan menikmati pertumbuhan pangsa pasar, penjualan, dan laba. Umumnya kinerja perusahaan diukur dan dievaluasi berdasarkan laba yang diperoleh. Para Stakeholder mengharapkan kinerja perusahaan mengalami peningkatan yang ditandai dengan peningkatan laba karena peningkatan laba akan meningkatkan pengembalian kepada pemegang saham. pemakai laporan keuangan akan mengetahui terjadi peningkatan atau penurunan kinerja keuangan suatu perusahaan dengan mengetahui pertumbuhan laba yang diperoleh perusahaan. Perubahan laba terjadi karena adanya pertumbuhan laba yang dihasilkan dari periode ke periode. Dengan melihat pertumbuhan laba disetiap periode dapat dijadikan dasar oleh para stakeholder untuk melakukan pengambilan keputusan.

\section{Analisis Laporan Keuangan}

Menurut Kasmir (2014) agar laporan keuangan menjadi lebih berarti sehingga dapat dipahami dan dimengerti oleh berbagai pihak, perlu dilakukan analisis laporan keuangan, dengan cara membagi satu angka dengan angka lainnya. Bagi owner dan manajemen tujuan utama analisis laporan keuangan adalah agar dapat mengetahui posisi keuangan perusahaan saat ini atau posisi ter-update. Selanjutnya, akan terlihat apakah perusahaan dapat mencapai target yang telah direncanakan sebelumnya atau sebaliknya dan menunjukkan kemampuan manajemen perusahaan dalam memberdayakan sumber daya perusahaan secara efektif. Hasil analisis laporan keuangan juga akan memberikan informasi tentang kelemahan dan kekuatan yang dimiliki oleh perusahaan.

Menurut Subramanyam dan Wild (2014), analisis laporan keuangan merupakan aplikasi dari alat dan teknik analitis laporan keuangan bertujuan umum dan data-data yang berkaitan untuk menghasilkan estimasi dan simpulan yang bermanfaat dalam analisis 
bisnis. Analisis laporan keuangan mengurangi ketergantungan pada firasat, tebakan, dan intuisi dalam pengambilan keputusan, serta mengurangi ketidakpastian analisis bisnis.

\section{Tujuan dan Manfaat Analisis Laporan keuangan}

Menurut Kasmir (2014) tujuan dan manfaat analisis laporan keuangan adalah :

1. Untuk mengetahui posisi keuangan perusahaan dalam satu periode tertentu, baik harta, kewajiban, modal, maupun hasil usaha yang telah dicapai untuk beberapa periode.

2. Untuk mengetahui kelemahan-kelemahan yang merupakan kekurangan perusahaan.

3. Untuk mengetahui kekuatan-kekuatan yang dimiliki.

4. Untuk mengetahui langkah-langkah perbaikan yang perlu dilakukan ke depan yang berkaitan dengan posisi keuangan perusahaan saat ini.

5. Untuk melakukan penilaian kinerja manajemen ke depan pakah perlu penyegaran atau tidak karena sudah dianggap berhasil atau gagal.

6. Dapat juga digunakan sebagai pembanding dengan perusahaan sejenis tantang hasil yang mereka capai.

\section{Rasio Keuangan}

Menurut Kasmir (2014) rasio keuangan merupakan kegiatan yang membandingkan angka-angka yang ada dalam laporan keuangan dengan cara membagi satu angka dengan angka lainnya. Perbandingan dapat dilakukan antar satu komponen dengan komponen dalam satu laporan keuangan atau antarn komponen dengan komponen dalam satu laporan keuangan atau antar komponen yang ada di antara laporan keuangan, kemudian angka yang diperbandingkan dapat berubah angka-angka dalam satu periode maupun beberapa periode.

\section{Rasio Likuiditas}

Rasio likuiditas bank yaitu rasio yang digunakan dalam mengukur seberapa besar tingkat likuid bank dalam melayani nasabahnya. Menurut Kasmir (2014) rasio likuiditas adalah untuk menunjukkan atau mengukur kemampuan perusahaan dalam memenuhi kewajibannya yang jatuh tempo, baik kewajiban kepada pihak luar perusahaan maupun di dalam perusahaan. Dengan kata lain, rasio likuiditas menunjukkan kemampuan perusahaan untuk membayar kewajiban jangka pendeknya yang jatuh tempo atau rasio yang digunakan untuk memenuhi kemampuan perusahaan dalam membiayai dan memenuhi kewajiban pada saat ditagih. Jenis-jenis rasio likuiditas yang digunakan dalam penelitian ini adalah: Current Ratio (CR) dan Cash Ratio.

\section{Rasio Solvabilitas}

Menurut Kasmir (2014) rasio solvabilitas merupakan rasio yang digunakan untuk mengukur sejauh mana aktiva perusahaan dibiayai dengan utang. Besarnya jumlah hutang yang digunkaan perusahaan untuk membiayai kegiatan usahanya jika dibandingkan dengan penggunaan modal sendiri. Artinya, berapa besar beban hutang yang ditanggung oleh perusahaan dibandingkan dengan aktivanya. Dalam arti luas bahwa rasio solvabilitas digunakan untuk mengukur kemampuan perusahaan membayar seluruh kewajibannya, baik jangka pendek maupun jangka panjang apabila perusahaan dibubarkan/dilikuidasi. Jenisjenis rasio solvabilitas yang digunakan dalam penelitian ini adalah : Debt to Asset Ratio (DAR) dan Time Interest Earned Ratio (TIE). 


\section{Rasio Profitabilitas}

Menurut Kasmir (2014) rasio profitabilitas merupakan rasio untuk menilai kemampuan perusahaan dalam mencari keuntungan. Rasio ini juga memberikan ukuran seberapa besar tingkat efektivitas dan efisiensi manajemen perusahaan. Hal ini dinyatakan dalam seberapa besar laba yang dihasilkan dari penjualan dan pendapatan investasi. Penggunaan rasio profitabilitas dapat dilakukan dengan menggunakan perbandingan antara berbagai komponen yang ada di laporan keuangan, terutama laporan keuangan neraca dan laporan laba rugi. Jenis-jenis rasio profitabilitas yang digunakan dalam penelitian ini adalah hanya Return On Asset (ROA).

\section{Rasio Keuangan Bank}

Rasio bank adalah rasio yang digunakan dalam menilai kinerja usaha bank dalam suatu periode akuntansi, akan tetapi disini rasio yang digunakan lebih bersifat kompleks daripada rasio-rasio yang digunakan dalam menilai kinerja perusahaan nonbank pada umumnya. Menurut Jumingan (2006) tujuan dari rasio keuangan bank adalah:

1. untuk mengetahui kemampuan kecukupan modal bank dalam mendukung kegiatan bank secara efisien.

2. untuk mengukur kemampuan bank dalam menyelesaikan kewajiban jangka pendek.

3. untuk mengetahui kemampuan bank dalam menghasilkan profit melalui operasi bank.

4. mengukur kemampuan pihak bank dalam menyanggah risiko dari aktivitas operasi.

5. untuk mengetahui kinerja manajemen dalam menggunakan semua assets secara efisien.

Menurut Kasmir (2012), rasio keuangan bank merupakan rasio yang digunakan perusahaan untuk mengukur keuangan yang dimiliki baik dalam memenuhi kewajiban, membiayai kegiatan operasional, dan tingkat efisiensi perusahaan. Rasio keuangan bank yang digunakan dalam penelitian ini adalah: Loan to Asset Ratio (LAR), Beban Operasional terhadap Pendapatan Operasional (BOPO), Reserve Requirement Ratio (RR), Non Performing Loan (NPL), dan Capital Adequacy ratio (CAR).

\section{Rasio Pasar}

Menurut Fahmi (2015) rasio nilai pasar yaitu rasio yang menggambarkan kondisi yang terjadi di pasar. Keputusan menempatkan dana di perusahaan terutama untuk masa yang akan dating sering menggunakan rasio pasar yang menyajikan kondisi perolehan keuntungan yang potensial dari suatu perusahaan. Jenis-jenis rasio nilai pasar yang digunakan dalam penelitian ini adalah: Price Earning Ratio (PER) dan Dividend Payout Ratio (DPR).

\section{Analisis Pertumbuhan Laba}

Tujuan utama perusahaan adalah memaksimalkan pencapaian laba. Oleh karena itu indikator yang sering digunakan dalam menentukan sukses tidaknya/berkinerja atau tidaknya manajemen perusahaan dalam mengoperasikan harta perusahaan adalah besarnya laba yang diperoleh perusahaan. Pengertian laba secara operasional adalah perbedaan antara pendapatan yang direalisasi yang muncul dari transaksi-transaksi selama satu periode dengan biaya yang berkaitan dengan pendapatan tersebut (Harahap, 2009). Menurut Wild dan Halsey (2005), Laba (income atau earnings atau profit) merupakan ringkasan hasil aktivitas operasi usaha yang dinyatakan dalam istilah keuangan. Laba mencerminkan pengembalian kepada pemegang ekuitas pada periode bersangkutan, sementara pos-pos 
dalam laporan merinci bagaimana laba didapat. Perusahaan pada level menengah ke atas umumnya telah dapat merencanakan laba dengan baik dengan tujuan pihak manajemen dapat mencapainya secara efektif. Dengan mengetahui tingkat pertumbuhan laba maka dapat membantu dalam pengambilan keputusan bagi para pemakai laporan keuangan. Umumnya para investor dalam menilai suatu perusahaan tidak hanya menilai laba dalam satu periode melainkan terus-menerus memantau perubahan laba perusahaan dari tahun ke tahun. Pertumbuhan laba yang baik menunjukkan bahwa perusahaan dapat mengelola dan menggunakan sumber daya yang ada di perusahaan secara efektif dan efisien.

Menurut Harahap (2009), pertumbuhan laba merupakan rasio yang menyatakan kemampuan perusahaan dalam meningkatkan laba bersih dibandingkan tahun sebelumnya. Oleh karena itu, pertumbuhan laba merupakan rasio yang menunjukan kemampuan perusahaan meningkatkan laba bersih dibandingkan tahun lalu. Jadi, dengan demikian diketahui pula kenaikan laba atau penurunan laba. Menurut Supriadi (2017), semakin tinggi tingkat pertumbuhan laba perusahaan maka semakin besar jumlah deviden yang akan dibayarkan perusahaan di masa yang akan datang. Hal ini disebabkan apabila perusahaan masih mempunyai kelebihan laba setelah membiayai semua kesempatan investasi yang dapat diterima, maka laba ini akan dibagikan kepada para pemegang saham dalam bentuk deviden kas.

Dalam penelitian ini, juga dianalisis pertumbuhan laba dalam rangka memprediksi laba perusahaan di masa yang akan datang. Menurut Angkoso (2006) ada dua macam analisis untuk menentukan pertumbuhan laba yaitu analisis fundamental dan analisis teknikal. Oleh karena itu, dalam penelitian ini digunakan analisis fundamental (analisis yang berhubungan dengan kondisi keuangan perusahaan) dan analisis teknikal (berupaya untuk memprediksi pertumbuhan laba di masa yang akan datang dengan mengamati perubahan laba di masa lalu).

\section{Hipotesis Penelitian}

$\mathrm{H}_{1}=$ Beban operasional terhadap pendapatan operasional (BOPO) berpengaruh terhadap pertumbuhan laba

$\mathrm{H}_{2}=$ Debt to Asset Ratio (DAR) berpengaruh terhadap pertumbuhan laba

$\mathrm{H}_{3}=$ Return on Equity (ROE) berpengaruh terhadap pertumbuhan laba

$\mathrm{H}_{4}=$ Loan to Asset Ratio (LAR) berpengaruh terhadap pertumbuhan laba

$\mathrm{H}_{5}=$ Reserve Requirement (RR) berpengaruh terhadap pertumbuhan laba

$\mathrm{H}_{6}=$ Non Performing Loan (NPL) berpengaruh terhadap pertumbuhan laba

$\mathrm{H}_{7}=$ Capital Adequacy Ratio (CAR) berpengaruh terhadap pertumbuhan laba

$\mathrm{H}_{8}=$ Dividen Payout Ratio (DPR) berpengaruh terhadap pertumbuhan laba

$\mathrm{H}_{9}=$ Current Ratio $(\mathrm{CR})$ berpengaruh terhadap pertumbuhan laba

$\mathrm{H}_{10}=$ Cash Ratio (Cash Ratio) berpengaruh terhadap pertumbuhan laba

$\mathrm{H}_{11}=$ Time Interest Eraned Ratio (TIE) berpengaruh terhadap pertumbuhan laba

$\mathrm{H}_{12}=$ Price Earning Ratio $(\mathrm{PER})$ berpengaruh terhadap pertumbuhan laba

$\mathrm{H}_{13}=$ BOPO, DAR, ROE, LAR, RR, NPL, CAR, DPR, CR, Cash Ratio, TIE, PER secara simultan berpengaruh terhadap pertumbuhan laba. 


\section{METODE PENELITIAN}

Rancangan penelitian yang digunakan adalah penelitian kausal (causal) atau hubungan sebab akibat. Sedangkan jenis data yang digunakan dalam penelitian ini berupa data sekunder berupa laporan tahunan (annual report) perusahaan perbankan yang terdaftar di BEI pada tahun 2012-2016, yang diperoleh melalui www.idx.co.id, data yang digunakan adalah data cross section. Teknik sampling yang digunakan dalam penelitian ini adalah teknik purposive sampling, yaitu teknik pengambilan sampel sumber data dengan pertimbangan tertentu (Sugiyono, 2013). Berdasarkan purposive sampling, populasi 43 perusahaan perbankan di BEI terdapat 29 perusahaan yang memiliki data tidak lengkap sehingga didapatkan besarnya sampel sebanyak 14 perusahaan. Berikut data perusahaan yang menjadi sampel penelitian disajikan pada Tabel 2.

Tabel 2. Sampel Penelitian

\begin{tabular}{cll}
\hline No & \multicolumn{1}{c}{ Nama Perusahaan } & \multicolumn{1}{c}{ Kode } \\
\hline 1 & PT.Bank Central Asia Tbk & BBCA \\
2 & PT.Bank Negara Indonesia (Persero) Tbk & BBNI \\
3 & PT.BankBukopinTbk & BBKP \\
4 & PT.Bank Rakyat Indonesia (Persero) Tbk & BBRI \\
5 & PT.Bank Tabungan Negara (Persero) Tbk & BBTN \\
6 & PT.BankDanamonTbk & BDMN \\
7 & PT.BankMandiri (Persero) Tbk & BMRI \\
8 & PT.BankPermataTbk & BNLI \\
9 & PT.Bank Victoria International Tbk & BVIC \\
10 & PT.Bank Mega Tbk & MEGA \\
11 & PT.Bank Pan Indonesia (Panin) Tbk & PNBN \\
12 & PT.Bank Nusantara ParahyanganTbk & BBNP \\
13 & PT.Bank ICB BumiputeraTbk & BABP \\
14 & PT.Bank CIMB NiagaTbk & BNGA \\
\hline
\end{tabular}

Sumber : www.idx.co.id

\section{Teknik Analisis Data}

Analisis regresi bertujuan untuk mengetahui besarnya pengaruh Rasio-Rasio Keuangan terhadap Pertumbuhan Laba Perusahaan Perbankan di BEI. Persamaan matematis untuk hubungan yang dihipotesiskan dapat dirumuskan sebagai berikut:

$\mathbf{Y}=\alpha+B_{1} X_{1}+B_{2} X_{2}+B_{3} X_{3}+B_{4} X_{4}+B_{5} X_{5}+B_{6} X_{6}+B_{7} X_{7}+B_{8} X_{8}+B_{9} X_{9}+B_{10} X_{10}+$ $B_{11} X_{11}+B_{12} X_{12}+e$

Keterangan:

$\mathrm{Y}=$ Alokasi Belanja Modal, $\mathrm{X} 1=\mathrm{BOPO}, \mathrm{X} 2=\mathrm{DAR}, \mathrm{X} 3=\mathrm{ROE}, \mathrm{X} 4=\mathrm{LAR}, \mathrm{X} 5=\mathrm{RR}, \mathrm{X} 6=\mathrm{NPL}, \mathrm{X} 7=\mathrm{CAR}, \mathrm{X} 8=$ DPR, X9 = CR, X10=Cash Ratio, X11= TIE, X12= PER, B $1, \mathrm{~B}_{2}, \ldots \mathrm{B}_{12}=$ Koefisien regresi, $\alpha=$ Konstanta, e $=$ error term

Selanjutnya peneliti melakukan uji asumsi yakni uji normalitas, uji multikolinearitas,uji heteroskedastisitas, dan uji autokorelasi untuk menguji kelayakan model regresi. Setelah model regresi dinyatakan layak maka dilakukan pengujian hipotesis dengan uji pengaruh simultan (F-test) dan uji pengaruh parsial (t-test). 


\section{HASIL PENELITIAN DAN PEMBAHASAN Pertumbuhan Laba}

Grafik berikut ini menggambarkan rata-rata pertumbuhan laba perusahaan perbankan periode 2011-2016 :

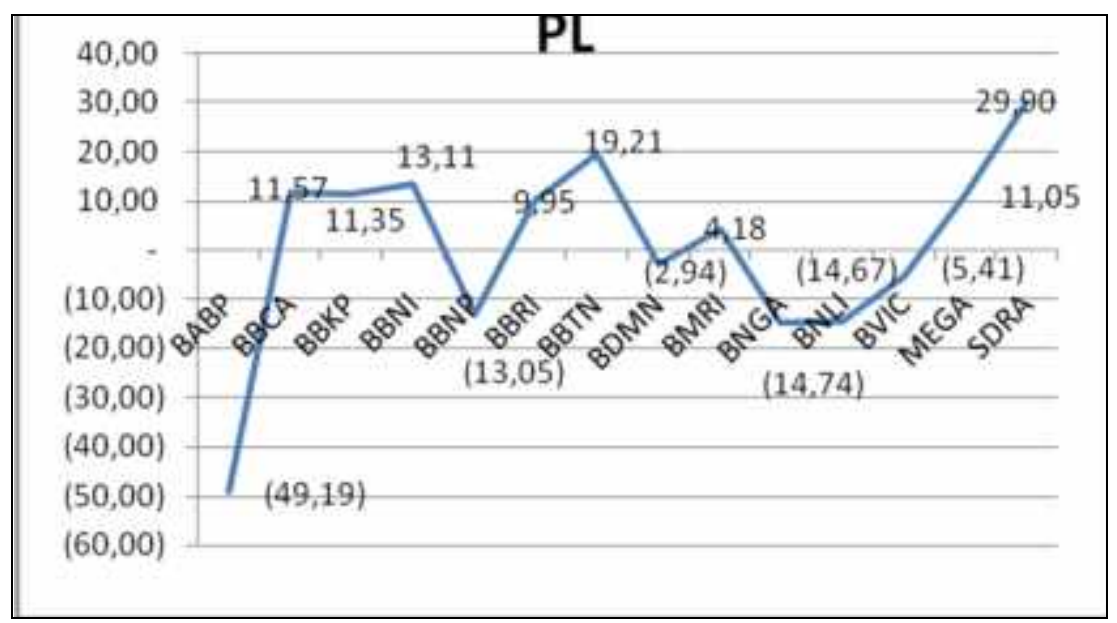

Gambar 2. Grafik Pertumbuhan Laba Perbankan di BEI Periode 2011-2016.

Berdasarkan grafik pertumbuhan laba di atas dapat diketahui bahwa hanya ada beberapa perusahaan yang memiliki persentase yang baik untuk di setiap tahunnya, namun banyak terdapat pula banyak perusahaan yang memiliki persentase pertumbuhan laba yang kurang baik. Pertumbuhan laba yang meningkat terjadi karena adanya keseimbangan antara biaya operasional terhadap pendapatan operasional perusahaan, begitu pula sebaliknya.

\section{Uji Asumsi Klasik}

Berdasarkan hasil uji normalitas, disimpulkan dari hasil pengujian Normal P-P Plot of Regression Standardized Residual bahwa pola distribusi yang mendekati normal. Hasil ini menunjukkan bahwa hasil regresi layak digunakan. Disamping itu, semua variabel yang digunakan dalam penelitian ini berdasarkan pengujian Colinearity Statistic memiliki tolerance yang lebih dari 0,1 dan nilai VIF yang kurang dari 10. Hal ini berarti bahwa variabel-variabel penelitian tidak menunjukkan adanya gejala multikolinearitas dalam model regresi. Berdasarkan hasil uji heteroskedastisitas terlihat titik-titik menyebar secara acak baik di atas maupun di bawah angka 0 pada sumbu $Y$ dan juga terlihat titik-titik tersebut membentuk suatu pola tertentu. Dengan demikian dapat disimpulkan bahwa penelitian ini terbebas dari masalah heteroskedastisitas. Hasil uji autokorelasi Durbin Watson dimana pada hasil tersebut diperoleh nilai DW sebesar 1.884 lebih besar dari batas 1.870 dan kurang dari 2.130, maka dapat disimpulkan bahwa tidak terjadi autokorelasi. 


\section{Hasil Uji Hipotesis}

Hasil pengujian hipotesis dapat dilihat pada tabel 4 berikut ini.

Tabel 4. Hasil Uji t (Uji Parsial)

\begin{tabular}{lcccc}
\hline \multicolumn{1}{c}{ Variabel } & Koefisien & $\mathrm{T}$ & $\mathrm{p}(\mathrm{sig})$ & Konfirmasi sig. \\
\hline BOPO & -.0310 & -1.250 & 0.216 & Tidak Bermakna \\
DAR & -2.160 & -1.836 & 0.072 & Tidak Bermakna \\
ROE & 2.463 & 2.777 & 0.007 & Bermakna \\
LAR & 0.018 & 0.046 & 0.963 & Tidak Bermakna \\
RR & -0.932 & -1.189 & 0.239 & Tidak Bermakna \\
NPL & -4.603 & -0.862 & 0.392 & Tidak Bermakna \\
CAR & -0.376 & -0.311 & 0.757 & Tidak Bermakna \\
DPR & -0.509 & -0.622 & 0.536 & Tidak Bermakna \\
CR & -13.672 & -0.277 & 0.782 & Tidak Bermakna \\
Cash_ratio & -0.680 & -0.787 & 0.435 & Tidak Bermakna \\
TIE & -1.432 & -0.445 & 0.658 & Tidak Bermakna \\
PER & -0.305 & -1.583 & 0.119 & Tidak Bermakna \\
\hline R Square $=0.440 \mathrm{~F}=3.736 \quad p(\operatorname{sig})=0.000$ & Konstanta $=242.078$ \\
Y = 242.078 $-0.310 \mathrm{X}_{1}-2.160 \mathrm{X}_{2}+2.463 \mathrm{X}_{3}+0.018 \mathrm{X}_{4}-0.932 \mathrm{X}_{5}-4.603 \mathrm{X}_{6}-0.376 \mathrm{X}_{7^{-}}$ \\
$0.509 \mathrm{X}_{8}-13.672 \mathrm{X}_{9}-0.680 \mathrm{X}_{10}-1.432 \mathrm{X}_{11}-0.305 \mathrm{X}_{12}$ & \multicolumn{4}{c}{}
\end{tabular}

Berdasarkan persamaan model regresi, maka hasil pengujian uji t dapat dijelaskan sebagai berikut:

1. Variabel Beban operasional terhadap pendapatan operasional (BOPO) terhadap Pertumbuhan Laba

Nilai t-hitung untuk variabel BOPO adalah sebesar -1.250 dan t-tabel dengan $\alpha=5 \%$ diketahui sebesar 2,003. Dengan demikian t-hitung lebih kecil dari t-tabel $(-1.250<$ 1.99444) dan nilai signifikansi sebesar $(0,216>0,05)$ artinya H0 diterima dan H1 ditolak, bahwa BOPO secara parsial tidak berpengaruh terhadap pertumbuhan laba. Tingkat efisiensi bank dalam menjalankan operasinya, berpengaruh terhadap tingkat pendapatan atau "earning" yang dihasilkan oleh bank tersebut. Jika kegiatan operasional dilakukan dengan efisien maka laba yang dihasilkan bank tersebut akan naik. Hal tersebut dapat dibuktikan dari hasil deskriptif yaitu nilai rata-rata BOPO per tahun cenderung naik. Sedangkan hasil dari nilai rata-rata PL mengalami kecenderungan penurunan.

2. Variabel Debt to Asset Ratio (DAR) terhadap Pertumbuhan Laba

Nilai t-hitung untuk variabel DAR adalah sebesar -1.836 dan t-tabel dengan $\alpha=5 \%$ diketahui sebesar 2,003. Dengan demikian t-hitung lebih kecil dari t-tabel $(-1.836<$ 1.99444) dan nilai signifikansi $(0.072>0,05)$ artinya H0 diterima dan H2 ditolak, bahwa DAR secara parsial tidak berpengaruh terhadap pertumbuhan laba. Hal tersebut menunjukkan bahwa perusahaan lebih banyak memanfaatkan alokasi dana dari hutang untuk memaksimalkan kekayaan perusahaan akan tetapi pemanfaatan dana dari hutang memiliki konsekuensi pada peningkatan beban bunga yang dibayarkan yang memberikan dampak pada penurunan laba perusahaan. Artinya ketidakmampuan DAR mempengaruhi pertumbuhan laba sangat dimungkinkan karena hasil penggunaan dana hutang untuk membiayai aktiva yang digunakan perusahaan tidak mampu menutupi 
seluruh beban bunga yang harus dibayar oleh perusahaan sehingga mengakibatkan penurunan laba yang diperoleh bahkan perusahaan bisa mengalami kerugian jika hal ini tidak di-mange dengan baik.

3. Variabel Return on Equity (ROE) terhadap Pertumbuhan Laba

Nilai t-hitung untuk variabel ROE adalah sebesar 2.777 dan t-tabel dengan $\alpha=5 \%$ diketahui sebesar 2,003. Dengan demikian t-hitung lebih besar dari t-tabel $(2.777>$ 1.99444) dan nilai signifikansi sebesar $(0.007<0,05)$ artinya $\mathrm{H} 0$ ditolak dan $\mathrm{H} 3$ diterima, bahwa ROE secara parsial berpengaruh signifikan positif terhadap pertumbuhan laba. Retun On Equity menyatakan besar kemampuan perusahaan dalam memberikan pengembalian atas investasi para pemegang saham. Semakin tinggi nilai ROE maka semakin baik karena nilai ROE yang tinggi menunjukkan kemampuan perusahaan dalam melakukan efisiensi untuk menghasilkan keuntungan dari setiap unit ekuitas. Ukuran seberapa baik suatu perusahaan menggunakan dana investasi untuk menghasilkan pertumbuhan laba dinyatakan dengan ROE. Hasil penelitian ini juga mendukung hasil penelitian yang dicapai oleh Angkoso (2006) yang menyimpulkan bahwa ROE berpengaruh terhadap pertumbuhan laba.

4. Variabel Loan to Asset Ratio (LAR) terhadap Pertumbuhan Laba

Nilai t-hitung untuk variabel LAR adalah sebesar 0.046 dan t-tabel dengan $\alpha=5 \%$ diketahui sebesar 2,003. Dengan demikian, t-hitung lebih kecil dari t-tabel $(0.046<$ 1.99444) dan nilai signifikansi sebesar $(0.963>0,05)$ artinya H0 diterima dan H4 ditolak, bahwa LAR secara parsial tidak berpengaruh terhadap pertumbuhan laba. LAR diperoleh dengan membandingkan total loan dengan total aktiva. Perusahaan perbankan yang mempunyai total loan yang semakin tinggi, maka perolehan laba juga meningkat akan tetapi risiko yang dihadapi risiko yang dihadapi perusahaan perbankan tersebut menjadi tinggi. Dengan kata lain, semakin tinggi LAR semakin kecil tingkat likuiditas perusahaan. Oleh karena itu, dalam penelitian ini LAR tidak berpengaruh terhadap pertumbuhan laba.

5. Variabel Reserve Requirement (RR) terhadap Pertumbuhan Laba

Nilai t-hitung untuk variabel RR adalah sebesar -1.189 dan t-tabel dengan $\alpha=5 \%$ diketahui sebesar 2,003. Dengan demikian t-hitung lebih kecil dari t-tabel $(-1.189<$ 1.99444) dan nilai signifikansi sebesar $(0.239>0,05)$ artinya H0 diterima dan H5 ditolak, bahwa RR secara parsial tidak berpengaruh terhadap pertumbuhan laba. Semua perusahaan perbankan telah menyisihkan lebih dari 5\% dana dari pihak ketiga yang dihimpun oleh perusahaan. Perusahaan juga dianggap telah mampu dalam menyimpan giro di Bank Indonesia bagi semua perusahaan perbankan yang bersumber dari dana pihak ke tiga. Dana pihak ketiga itu terdiri dari tabungan deposito dan kewajiban segera. Oleh karena RR dalam rangka memenuhi ketentuan perbankan maka besarnya RR tidak berpengaruh pada pertumbuhan laba. Artinya RR sifatnya dana cadangan yang disimpan pada Bank Indonesia yang tidak dapat diganggu atau digerakkan untuk meningkatkan laba perusahaan perbankan.

6. Variabel Non Performing Loan (NPL) terhadap Pertumbuhan Laba

Nilai t-hitung untuk variabel NPL adalah sebesar -0.862 dan t-tabel dengan $\alpha=5 \%$ diketahui sebesar 2,003. Dengan demikian t-hitung lebih kecil dari t-tabel $(-0.862<$ 
1.99444) dan nilai signifikansi sebesar $(0.392>0,05)$ artinya H0 diterima dan H6 ditolak, bahwa NPL secara parsial tidak berpengaruh terhadap pertumbuhan laba. Hal tersebut dapat dibuktikan dari hasil deskriptif yaitu nilai rata-rata NPL per tahun cenderung naik. Sedangkan hasil dari nilai rata-rata PL mengalami kecenderungan penurunan. Oleh karena itu, perusahaan yang memiliki rasio NPL rendah tidak dapat ditentukan bahwa perusahaan tersebut akan dapat meningkatkan pertumbuhan laba dibandingkan dengan perusahaan yang memiliki rasio NPL yang tinggi. NPL pada sampel perusahaan perbankan berdasarkan data pada Tabel 4. Statistik Deskriptif Data Variabel Penelitian mempunyai nilai rata-rata sebesar 1.5209 atau $152.09 \%$ yang artinya kemampuan manajemen bank dalam mengelola kredit sudah baik karena masih dalam predikat sehat, sehingga biaya pencadangan aktiva produktif maupun biaya lainnya yang harus dikeluarkan oleh perusahaan perbankan juga akan semakin rendah dan akan berpotensi terhadap kenaikan laba bank.

7. Variabel Capital Adequacy Ratio (CAR) terhadap Pertumbuhan Laba

Nilai t-hitung untuk variabel CAR adalah sebesar -0.311 dan t-tabel dengan $\alpha=5 \%$ diketahui sebesar 2,003. Dengan demikian t-hitung lebih kecil dari t-tabel $(-0.311<$ 1.99444) dan nilai signifikansi sebesar $(0.757>0,05)$ artinya $\mathrm{H} 0$ diterima dan $\mathrm{H} 7$ ditolak, bahwa CAR secara parsial tidak berpengaruh terhadap pertumbuhan laba. Koefisien CAR sebesar -0.311 menunjukkan CAR berhubungan negatif terhadap pertumbuhan laba. Pengaruh negatif yang ditunjukkan oleh CAR mengindikasikan bahwa apabila CAR mengalami kenaikan, maka pertumbuhan laba juga akan mengalami penurunan, dan sebaliknya. Hal ini dapat dibuktikan dari hasil deskriptif yaitu nilai ratarata CAR per tahun yang bergerak naik sedangkan PL perusahaan perbankan flutuatif dan cenderung menurun. Sedangkan hasil dari nilai rata-rata pertumbuhan laba mengalami penurunan di setiap tahunnya, jadi perusahaan yang memiliki CAR tinggi atau rendah tidak memiliki pengaruh terhadap pertumbuhan laba.

8. Variabel Dividen Payout Ratio (DPR) terhadap Pertumbuhan Laba

Nilai t-hitung untuk variabel DPR adalah sebesar -0.622 dan t-tabel dengan $\alpha=5 \%$ diketahui sebesar 2,003. Dengan demikian t-hitung lebih kecil dari t-tabel $(-0.622<$ 1.99444) dan nilai signifikansi sebesar $(0.536>0,05)$ artinya H0 diterima dan H8 ditolak, bahwa DPR secara parsial tidak berpengaruh terhadap pertumbuhan laba. Hasil penelitian ini tidak sesuai dengan teori yang menyatakan pembayaran dividen merupakan sinyal positif bagi para investor. Dividen yang tinggi mencerminkan baiknya kinerja manajer perusahaan juga meningkatkan kemakmuran investor. Dalam penelitian ini DPR tidak berpengaruh terhadap pertumbuhan laba disebabkan kurang bersikap tegas dalam menentukan kebijakan dividennya. Kekurangan modal dapat mengakibatkan perusahaan khawatir apabila dividen yang dibayarkan penuh, namun dividen yang dibayar rendah bisa mengakibatkan investor kurang percaya sebagai akibat kurang diperhatikannya tingkat kemakmuran mereka.

9. Variabel Current Ratio (CR) terhadap Pertumbuhan Laba

Nilai t-hitung untuk variabel CR adalah sebesar -0.277 dan t-tabel dengan $\alpha=5 \%$ diketahui sebesar 2,003. Dengan demikian t-hitung lebih kecil dari t-tabel $(-0.277<$ 1.99444) dan nilai signifikansi sebesar $(0.782>0,05)$ artinya H0 diterima dan H9 
ditolak, bahwa CR secara parsial tidak berpengaruh terhadap pertumbuhan laba. Hal tersebut menunjukkan kemampuan perusahaan dalam memenuhi kewajiban jangka pendek tidak dapat memberikan jaminan ketersediaan modal kerja yang mendukung aktivitas operasional perusahaan yang menyebabkan perolehan laba yang ingin dicapai menjadi tidak sesuai ekspektasi. Artinya aktiva lancar yang dihasilkan terlalu tinggi karena perusahaan berusaha untuk sedapat mungkin menggunakan aktiva lancar tidak hanya memenuhi hutang tetapi juga untuk kepentingan yang lain. Hal ini akan menyebabkan terjadinya kelebihan aktiva lancar yang akan berpengaruh tidak baik terhadap pertumbuhan laba. Oleh karena aktiva lancar pada umumnya menghasilkan return yang lebih rendah dibandingkan dengan aktiva tetap.

10 Variabel Cash Ratio terhadap Pertumbuhan Laba

Nilai t-hitung untuk variabel Cash Ratio adalah sebesar -0.787 dan t-tabel dengan $\alpha=$ $5 \%$ diketahui sebesar 2,003. Dengan demikian t-hitung lebih kecil dari t-tabel $(-0.787<$ 1.99444) dan nilai signifikansi sebesar $(0.435>0,05)$ artinya $\mathrm{H} 0$ diterima dan $\mathrm{H} 10$ ditolak, bahwa cash ratio secara parsial tidak berpengaruh terhadap pertumbuhan laba. Hal tersebut menunjukkan kemampuan perusahaan dalam memenuhi kewajiban jangka pendek tidak dapat memberikan jaminan ketersediaan modal kerja yang mendukung aktivitas operasional perusahaan yang menyebabkan perolehan laba yang ingin dicapai menjadi tidak sesuai ekspektasi. Artinya kas yang dihasilkan terlalu tinggi karena perusahaan berusaha untuk sedapat mungkin menggunakan aktiva lancar tidak hanya memenuhi hutang tetapi juga untuk kepentingan yang lain. Hal ini akan menyebabkan terjadinya kelebihan kas yang akan berpengaruh tidak baik terhadap pertumbuhan laba. Oleh karena kas pada umumnya menghasilkan return yang lebih rendah dibandingkan dengan aktiva tetap.

11 Variabel Time Interest Eraned Ratio (TIE) terhadap Pertumbuhan Laba

Nilai t-hitung untuk variabel TIE adalah sebesar 0.658 dan t-tabel dengan $\alpha=5 \%$ diketahui sebesar 2,003. Dengan demikian t-hitung lebih kecil dari t-tabel $(0.658<$ 1.99444) dan nilai signifikansi sebesar $(0.658>0,05)$ artinya $\mathrm{H} 0$ diterima dan $\mathrm{H} 11$ ditolak, bahwa TIE secara parsial tidak berpengaruh terhadap pertumbuhan laba. Hal ini disebabkan karena telah terjadinya penurunan yang tidak stabil pada laba sebelum pajak yang dimiliki perusahaan sehingga laba pun menurun.

12 Variabel Price Earning Ratio (PER) terhadap Pertumbuhan Laba

Nilai t-hitung untuk variabel PER adalah sebesar -1.583 dan t-tabel dengan $\alpha=5 \%$ diketahui sebesar 2,003. Dengan demikian t-hitung lebih kecil dari t-tabel $(-1.583<$ 1.99444) dan nilai signifikansi sebesar $(0.119>0,05)$ artinya H0 diterima dan H12 ditolak, bahwa PER secara parsial tidak berpengaruh terhadap pertumbuhan laba. PER menyatakan seberapa besar investor bersedia untuk membayar persatuan mata uang dari keuntungan yang dilaporkan perusahaan dan menjadi komponen yang cukup penting. PER juga menyatakan apresiasi pasar terhadap kemampuan perusahaan dalam menghasilkan laba. Semakin kecil nilai PER maka semakin murah harga saham tersebut untuk dibeli begitu juga sebaliknya. Hasil penelitian menunjukkan PER tidak mempunyai pengaruh yang signifikan terhadap harga saham. Hal ini mengindikasikan PER bukan merupakan indikasi bagi investor dalam menanamkan sahamnya. Artinya, 
investor mungkin mencari capital gain dibandingkan dengan deviden, yang dapat diartikan investor lebih memilih keuntungan jangka pendek dibandingkan dengan jangka panjang.

Tabel 5. Model Summary

\begin{tabular}{lrrrrr}
\hline Model & $\mathrm{R}$ & R Square & Adjusted R Square & $\begin{array}{c}\text { Std. Error of the } \\
\text { Estimate }\end{array}$ & Durbin-Watson \\
\hline 1 & $.664^{\mathrm{a}}$ & .440 & .322 & 32.13602 & 1.884 \\
\hline a. Predictors: (Constant), PER, CAR, LAR, TIE, Cash_ratio, CR, ROE, BOPO, DPR, RR, NPL, DAR \\
b. Dependent Variable: PL
\end{tabular}

Berdasarkan hasil perhitungan bahwa Nilai Adjusted $R$ Square atau koefisien determinasi adalah sebesar 0,322. Hal ini berarti 32,2\% variabel pertumbuhan laba (variabel dependen) mampu dijelaskan oleh BOPO, DAR, ROE, LAR, RR, NPL, CAR, DPR, CR, Cash Ratio, TIE, PER (variabel independen), sedangkan sisanya sebesar 67,8\% dipengaruhi oleh faktor lain yang tidak dijelaskan dalam penelitian ini.

Tabel 6. Hasil Uji F (Simultan)

\begin{tabular}{|c|c|c|c|c|c|c|}
\hline Model & & Sum of Squares & $d f$ & Mean Square & $\mathrm{F}$ & Sig. \\
\hline \multirow{3}{*}{1} & Regression & 46299.308 & 12 & 3858.276 & 3.736 & $.000^{\mathrm{a}}$ \\
\hline & Residual & 58865.272 & 57 & 1032.724 & & \\
\hline & Total & 105164.580 & 69 & & & \\
\hline
\end{tabular}

Berdasarkan hasil pengolahan data dengan program SPSS Versi 23, maka didapat F-hitung sebesar 3,736 dengan tingkat signifikansi sebesar 0,000. Df pembilang 12 sedangkan df penyebut adalah 70 sehingga F-tabel diketahui sebesar 3,736. Berdasarkan hasil tersebut dapat diketahui bahwa F-hitung > F-tabel $(3,736>1.86)$ maka H0 ditolak dan Ha diterima. Sehingga dapat disimpulkan bahwa variabel BOPO, DAR, ROE, LAR, RR, NPL, CAR, DPR, CR, Cash Ratio, TIE, PER secara simultan berpengaruh signifikan terhadap pertumbuhan laba perusahaan perbankan yang terdaftar di BEI periode 2012-2016. Hasil penelitian ini menunjukkan bahwa pada perusahaan perbankan peran rasio-rasio BOPO, DAR, ROE, LAR, RR, NPL, CAR, DPR, CR, Cash Ratio, TIE, PER sangat perlu diperhatikan karena mendukung pertumbahan laba khususnya pada rasio ROE yang secara simultan dan parsial berpengaruh terhadap pertumbuhan laba. ROE memiliki fungsi sebagai pengukur tingkat keuntungan yang didapatkan para investor untuk penanaman modal yang telah dilakukan pada perusahaan emiten. Semakin tinggi rasio ROE yang positif maka semakin menunjukkan besarnya kemampuan perusahaan perbankan dalam menghasilkan laba dengan menggunakan modal sendiri yang dapat menguntungkan para pemegang saham. Dengan demikian, penting bagi investor khususnya untuk mempertimbangkan rasio ROE perusahaan perbankan tersebut sebelum mengambil keputusan investasi.

\section{E. PENUTUP}

Hasil penelitian menunjukan bahwa hanya variabel ROE yang berpengaruh secara parsial terhadap pertumbuhan laba pada perusahaan perbankan di BEI periode 2012-2016. Sedangkan BOPO, DAR, ROE, LAR, RR, NPL, CAR, DPR, CR, Cash Ratio, TIE, PER secara simultan berpengaruh signifikan terhadap pertumbuhan laba pada perusahaan perbankan di BEI periode 2012- 
2016. Bagi perusahaan perbankan sangatlah penting untuk memperhatikan rasio-rasio keuangan yang mengukur kinerja perusahaan khususnya yang menentukan tingkat kesehatan bank tersebut. Bagi investor adalah penting untuk menilai kinerja keuangan tidak hanya terbatas pada perusahaan sebagai satu kesatuan akan tetapi menilai juga kelompok industrinya. Keterbatasan penelitian ini adalah jumlah sampel, data laporan keuangan yang digunakan hanya lima tahun, pengkategorian bank, dan tidak memasukkan faktor teknikal ke dalam penelitian ini. Bagi peneliti lanjutan disarankan untuk mengkaji faktor-faktor pertumbuhan laba lainnya, misalnya: umur perusahaan, besarnya perusahaan, tingkat leverage, tingkat penjualan, perubahan laba masa lalu, dan variabel lainnya.

\section{DAFTAR PUSTAKA}

Angkoso, W Ciptadi. 2006. Pengaruh Debt Ratio dan Return On Equity Terhadap Pertumbuhan Laba di Bursa Efek Jakarta. diakses 13 Juli 2017)

Fahmi, I. 2014. Manajemen Keuangan Perusahaan dan Pasar Modal. Edisi Pertama. Mitra Wacana Media. Jakarta.

Ghozali dan Chariri, 2007. Teori Akuntansi. Semarang: Badan Penerbit Undip.

Gunawan, Ade dan Sri Fitri Wahyuni. 2013. Pengaruh Rasio Keuangan terhadap Pertumbuhan Laba pada Perusahaan Perdagangan di Indonesia. Jurnal Manajemen \& Bisnis Vol 13 No. 01 April 2013 ISSN 1693-7619.

Harahap, Sofyan Syafri. 2009. Analisis Kritis atas Laporan Keuangan. Jakarta: Raja Grafindo Persada.

Jumingan, 2006. Analisis Laporan Keuangan, Cetakan Pertama, PT Bumi Aksara, Jakarta.

Kasmir. 2014. Bank dan Lembaga Keuangan Lainnya. Edisi Revisi, Cetakan keempat belas, PT. Raja Grafindo Persada, Jakarta.

Mahaputra, I Nyoman Kusuma Adnyana. 2012. Pengaruh Rasio-Rasio Keuangan terhadap Pertumbuhan Laba pada Perusahaan Manufaktur yang Terdaftar di BEI. Vol. 7, No. 2, Juli 2012. AUDI Jurnal Akuntansi \& Bisnis.

Mujati S, Yuniep dan Meida Dzulqodah. 2016. Pengaruh Earning Per Share dan Price Earning Ratio terhadap Debt To Equity Ratio dan Harga Saham pPada Perusahaan Sektor Makanan dan Minuman di Bursa Efek Indonesia. EKSIS Vol XI No 1, 2016 ISSN: 1907-7513.

Oktanto, Danny dan Muhammad Nuryanto. 2014. Pengaruh Rasio Keuangan Terhadap Perubahan Laba Pada Perusahaan Manufactur Yang terdaftar di bursa efek indonesia (BEI) Tahun 2008-2011. Jurnal Akuntansi, Volume 1 No 77.

Purwanto, Hendri. 2017. Pengaruh Kesehatan Keungan Bank Terhadap Pertumbuhan Laba Pada Perusahaan Bank Go-Publik Di Bursa Efek Indonesia (BEI) Periode 2010-2014. Jurnal Pendidikan Ekonomi, Volume 6, Nomor 2, Tahun 2017.

Safitri, Isnaniah Laili Khatmi. 2016. Pengaruh Rasio Keuangan terhadap Pertumbuhan Laba pada Perusahaan Manufaktur Sektor Industri Konsumsi yang Terdaftar di Bursa Efek Indonesia (Studi Kasus pada Perusahaan Kalbe Farma Tbk Periode 2007-2014). Jurnal Akuntansi dan Bisnis Volume 2 Nomor 2 Nopember 2016.

Subramanyam, K.R \& John J, Wild. 2014, Analisis Laporan Keuangan, Buku 1, Salemba Empat, Jakarta.

Sugiyono. 2013. Metode Penelitian Pendidikan Pendekatan Kuantitatif, Kualitatif, dan R\&D. Bandung: Alfabeta. 
Supriadi. 2015. Analisis Pengaruh Perubahan Laba, Debt To Equity Ratio (DER), dan Ukuran Perusahaan terhadap Return Saham pada Perusahaan Makanan dan Minuman (Food And Beverage) yang Go Publik di Bursa Efek Indonesia (BEI). EKSIS. Vol X No 2, Oktober 2015. ISSN: 1907-7513.

Undang-Undang No.10 tahun 1998 tentang Perbankan. Sekertariat Negara RI

Wild, John, K.R. Subramanyam, dan Robert F. Halsey. 2005. Analisis Laporan Keuangan. Edisi Delapan, Buku Kesatu. Alih Bahasa : Yanivi dan Nurwahyu. Jakarta: Salemba Empat.

Yasmin, Yessy. 2017. Analisis Rasio Keuangan untuk Menilai Kinerja Keuangan Perusahaan Farmasi di BEI Yessy Yasmin. Jurnal Ilmu dan Riset Manajemen Volume 6, Nomor 2, Februari 2017 ISSN : 2461-0593. 